\title{
Blending Problem Based Learning with Scientific Argumentation to Enhance Students' Understanding of Basic Genetics
}

\section{Tashi Choden}

Science Education, Faculty of Education, Naresuan University, Thailand, tashicd07@hotmail.com

\section{Sirinapa Kijkuakul}

Dr., Science Education, Faculty of Education, Naresuan University, Thailand, sirinapaki@nu.ac.th

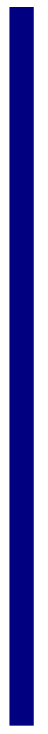

Genetics can be a difficult topic to teach and learn in a traditional classroom. The objective of this qualitative classroom action research was to examine the effectiveness of a blend of problem-based learning (PBL) with scientific argumentation to improve student understanding of basic genetics. The research participants were grade 9 Bhutanese students accustomed to rote learning placed in small groups to competitively achieve a solution utilizing PBL and scientific argumentation. The six-week teaching intervention process was teacher evaluated daily and at the end of each unit followed by strategy and lesson adjustments by applying the cycles of action research: planning, acting, observing, and reflecting while considering the pre- and post-genetic tests, lesson plans, semi-structured observations, pre- and post-semi structured interviews, reflective journals, and, student learning tasks. Content analysis and method triangulation were used to confirm that the blending approach was effective in helping students to acquire basic knowledge and to eliminate most misconceptions about five central subtopics in the study of genetics: inheritance, variation, genetic engineering, cloning and evolution. An assessment of teacher journals and outsider evaluations of teacher lessons and presentations revealed an increasing teacher appreciation for the blended method. This intervention helped students become independent and active learners.

Keywords: classroom action research, genetics, problem-based learning, scientific argumentation, learning

\section{INTRODUCTION}

Genetics is a difficult and complex unit to teach but it is important in many facets of society as regards to genetically modified organisms, DNA testing, disease

Citation: Choden, T., \& Kijkuakul, S. (2020). Blending Problem Based Learning with Scientific Argumentation to Enhance Students' Understanding of Basic Genetics. International Journal of Instruction, 13(1), 445-462. https://doi.org/10.29333/iji.2020.13129a 
identification, cloning etc. (NIH, 2010). Difficulties could be due to the misconceptions students and teachers have about various subtopics in genetics as revealed in the findings of several studies in grades 7-12 (Altunoglu \& Seker, 2015; Osman et al., 2017; Shaw et al., 2008; Yates \& Marek, 2013). Adding to the difficulty was the students' preconceptions of the genetics that were obtained from a previous class or due to the errors found in the curriculum statement and in the textbooks (Nusantari, 2014; Sanders \& Makotsa, 2016).

In Bhutan, genetics was introduced in the science curriculum in 2016 for grades 9-12 (Royal Education Council, 2016) with the subtopics of inheritance, variation, genetic engineering, cloning and evolution to be taught in grade 9. Two recent studies for grade 10 students (Dorji et al., 2017) and grade 11 students (Dorji \& Sriwattanarothai, 2015) in Bhutan revealed that the students had misconceptions about genetics and had difficulty understanding the advanced concepts. Kılıç \& Sağlam (2014) found that while the study of genetics requires high levels of reasoning, students lacked a sound understanding of genetics and often attempt to learn the subject by rote in a traditional classroom. The recognition of the misconceptions and difficulties in teaching genetics as well as the prevalence of traditional teaching approaches has prompted concern to conduct research and report the effectiveness of non- traditional approaches.

The new Bhutanese science curriculum design is student-centered with its goals to enable students to acquire scientific knowledge and understanding of natural science (DCRD, 2011). However, most teachers and students prefer traditional lecture method resulting in a mismatch between curriculum developers' intentions and classroom practice (Dolma et al., 2018; Namgyel, 2005).

There are a number of approaches for effectively teaching difficult concepts in a nontraditional manner that possibly could address the needs outlined above (Rodríguez et al., 2018). Problem-based learning (PBL) is one approach which is an active learning approach characterized by finding solutions to real life problems and difficult subjects like genetics where students are given the chance to discover and learn by themselves (Barrett \& Moore, 2010). Another is scientific argumentation which is an important approach used to develop understanding of science as it provides students opportunities to express their thoughts based on their findings by generating evidence-based claims with theoretical backing to judge their own and others' ideas (Cavagnetto, 2010; Pei et al., 2019).

It was observed that PBL alone did not achieve the purpose of the study, as the solutions to the ill-structured problems were hypothetical and it was found that scientific argumentation gave the solution more significance due to the evidence and justifications (Belland et al., 2011). The idea of blending two approaches was discussed and found to have a positive impact on teaching and learning (Donnelly, 2006).In order to facilitate the research undertaken, scientific argumentation was introduced with PBL and found these two approaches complemented each other well (Fielding-Wells, 2015).The transition and the implementation requirements of PBL with scientific argumentation were determined by the classroom action research based on the comparisons of genetic tests and interviews. 


\section{LITERATURE REVIEW}

Genetics is a topic of great significance in modern education and can be regarded as the cornerstone of scientific literacy, demanding students' comprehension and understanding (Altunoğlu \& Şeker, 2015; Dorji et.al.2017). This understanding is related to misconceptions across grades 7-12, on various sub-topics: DNA, chromosomes, genes, genetic variation, genetic technology, genetic inheritance, cloning, mutation, evolution, etc. It is beneficial to find misconceptions first as they are very important for learning progression in genetics (Osman et al., 2017, Putri et al., 2017, Queloz et al., 2017; Shaw et al., 2008). Researchers in Bhutan, (Dorji \& Sriwattanarothai,2015; Dorji et al.,2017), identified specific misconceptions among grade 10 and 11 Bhutanese students in the domain of molecular biology, Mendelian genetics and evolution, and confusion about DNA, genes and chromosomes, and the roles of protein and RNA. Some examples are the misappropriation of genetic terms like characteristics and phenotypes. Students also understood both genes and DNA as the same aspects of genetics which is not correct. A few students had the misconception that gene mutation or natural selection is the source of the origin of life. The results indicated that students had misconceptions in basic concepts of genetics in biology which should have been clarified in grade nine where the basics of Genetics are to be introduced.

Most biology teachers prefer to teach in a traditional lecture method as it was found to be easier and faster to cover the syllabus on time but this way of teaching hindered the students understanding of Genetics so misunderstandings were found even after instruction where students depended on rote learning to pass the examination (John et al., 2019). Because of this, it has been considered that the use of motivational active learning (implemented as a mix of methodologies) will make the students more alert, motivated and highly participative, being interested in the subject and thus enhancing their performance (Rodríguez et al., 2018)

Problem based learning is an authentic, experiential form of learning centered on the collaborative investigation and resolution of real-world problems (Fernandez, 2017). A lot of teaching models encourage student centered learning but the reason for choosing a problem-based approach was because it resulted in greater student involvement in classroom activities with self-guided learners being actively engaged in constructing new knowledge by identifying and solving ill-structured problems that are relevant to daily life through discussion and positive argumentation. Past studies have compared the effectiveness of PBL with traditional lecture-based instruction in enhancing students' academic achievement and performance skills, especially in genetics, and have demonstrated that PBL was effective in enabling students to more successfully acquire scientific understanding of, and overcoming misconceptions related to Genetics (Araz \& Sungur, 2007; Suarez, 2017).

The characteristics of PBL are; (a) It is student-centered with students learning in small groups guided by a tutor who is the facilitator and students solve authentic problems.; (b) Learning is initiated and framed as an ill-structured problem, which should be solved by argumentation; (c) Learning in collaborative teams; (d) Information learned through 
inquiry or research is related back to the problem; (e) Students become increasingly selfdirected learners over the course of PBL experience (Baele, 2017; Marra et al., 2014; McConnell , 2016).

The concept of scientific argumentation is an important aspect of the process of scientific inquiry which requires students to find enough evidence and justification to support their claim. Toulmin's argumentation pattern or model was adopted which requires students to construct an argument consisting of a claim, their evidence and their reasoning (Zahrok et al., 2017; Toulmin, 2003). The process was often assisted by the researcher as a facilitator who ensured that the scientific argumentation was going in the right direction and provided help to the students to converge on the best solution to the problem (Araz \& Sungur, 2007). Here, the research method defines the concept of claim as being the best solution to the ill-structured genetic problem. The evidence component of an argument refers to measurements or observations that are used to support the validity or the legitimacy of the claim, and the reasoning component indicates why the evidence supports the claim. Scientific argumentation, if successfully carried out, can result in the development, evaluation and validation of scientific knowledge and also encourage a deeper understanding of the theories and principles in science (Cavagnetto, 2010; Sampson et al., 2011). A study done by Zohar \& Nemet (2002) revealed that scientific argumentation helped to enhance the students' performance in biological knowledge in human genetics as approximately $90 \%$ of the students were successful in formulating simple arguments.

PBL alone can find the solution to the ill-structured problem and there is no right or wrong solutions in PBL, while scientific argumentation alone can support the validity of a claim.By blending PBL with scientific argumentation, a solution to the ill-structured problem that has been chosen by the students as the best one can be supported by logical evidence (facts and figures) and the reasoning validated by scientific argumentation (Ju \& Choi, 2018; Wirkala \& Kuhn, 2011). It was mentioned in a study that when the students engage in argumentation to solve a problem, it resulted in deeper conceptual understanding, retained learning outcome longer and transferred their learning more effectively (Tawfik et al., 2018).

To observe the effectiveness of these two approaches, classroom action research has been acknowledged as a powerful tool for teachers as a way to find solutions for problems in their specific educational setting, to inform and improve their own teaching approach. (Hien, 2016; Kemmis \& McTaggart, 2005; Maxwell, 2003).

One such classroom action research model by Kemmis \& McTaggart (2005) was chosen for this study because it was relatively easy to understand and follow and was consistent in terms of the research process. Teachers apply classroom action research in terms of a qualitative interpretation of their own practice by recognizing their own strengths and weaknesses in teaching practice and in resolving significant problems in the classroom, also considered in (Hine, 2013, p. 152). Application of action research makes it possible for teachers to determine if their PBL students learned as much or more content in a problem designed around the issue of possible genetic causes than did students in a more traditional genetics unit (Torp, 2002). 


\section{METHOD}

This study referred a qualitative classroom action research (CAR) model by Kemmis \& McTaggart (2005) which involved cycles of plan-act-observe-reflect actions with each cycle informing the next and eventually leading to improved teaching and learning outcomes in the classroom (Fernandez, 2017; Kemmis \& McTaggart, 2005).

In this research, the planning was done based on the results of the pre-genetic test and the pre-semi structured interview done on all five units. This helped the researcher get an idea of students' conceptions and misconceptions in genetics. Five lessons were planned roughly based on the objectives of the five units in genetics: inheritance, variation, genetic engineering, cloning and evolution to improve the conceptions of basic genetics and to clarify the misconceptions.

The applications of the plan or the action phase of the cycle was planned for 3 periods of 50 minutes each during which the students carried out the PBL activity with scientific argumentation that was adapted and modified variously from Sage \& Torp (2002); McConnell(2016); Toulmin (2003).The study, referred to as the intervention to reflect the action research principles of actually intervening in the activity being studied, included 6 steps that were divided into three teaching periods of 50 minutes each in a week. Steps 1-2 in the first period, Step 3-4 in the second period and steps 5-6 in the third period.

The steps were:

1. Introduce the first part as an ill-structured problem to arouse students' curiosity.

2. Allow small group discussions within three categories, "what do we know?", "What do we need to know?" and "Hypotheses".

3. The second part of the story is given to challenge the students with more information on the problem, and the students in their small heterogeneous groups seek their best solutions and claim one of the solutions as their best.

4. Identify the topics sufficiently to enable a search for information and evidence for students' claim, with good reasoning, to support the students' decision to prove that selection as being the best choice.

5. Whole class discussion was then essential for scientific argumentation. The student representatives from each group will claim the solution they chose to be the best with evidence reasoning. Others can produce rebuttals to prove that that claim is wrong.

6. Ultimately, the students should arrive at a mutually agreed consensus that a particular claim is the best solution to the problem.

So, the acting phase involving the 6 steps of PBL activity was carried out for 3 periods of 50 minutes each where constant observations and reflections were made after each period in a daily journal and the reflections analyzed at the end of 3 periods of each cycle so that the weaknesses are addressed in the next cycle. However, each individual teacher could use these teaching plans as a guide for replication with adjustments according to their classroom context. 
The researcher assessed the students and the effectiveness of the class following the steps of action research informally at the end of each day. A critical friend's observation from time to time and video recordings of the lessons helped the researcher to observe and reflect. Reflections were recorded after every lesson and analyzed at the end of $3^{\text {rd }}$ period of each cycle to plan for the next cycle. Thus, the teaching of each unit evolved as the students became more familiar with the PBL and scientific argumentation and the teacher shaped the next lessons to meet learning needs and abilities based on a scientific action plan.

\section{Participants}

The participants of this study were Grade 9 students of a secondary school in Bhutan consisting of 14 males and 17 female students $(n=31)$. They were selected randomly from one section of grade 9 comprising of mixed ability students as the basic foundation of genetics starts in grade nine in Bhutan and this is where all the misconceptions in genetics are carried onward and forward. Most of the students were from middle-income group families with diverse mother tongue but the medium of instruction was English in the classroom.

\section{Research Instruments}

Instruments for data collection used during the study included 5 lesson plans with 15 teaching periods overall, with each cycle lasting for 3 teaching periods, a reflective journal, pre- and post- genetic tests, pre-post semi-structured interview, and students' learning tasks. The instruments were verified by subject experts prior to data collection.

Lesson plan -The 5 lesson plans were used as the guidelines to conduct 15 teaching periods in total. Each cycle was planned for 3 periods of 50 minutes each in a week. Lesson plans were checked and verified by the two experts in biology and science education. Each lesson had clear objectives, description of materials needed, a thorough procedure with an opening and a closing including students' activities as well as assessments and modifications.

Pre and post genetics tests-Both the tests consisted of 13 two-tiered multiple-choice questions that covered 5 main subtopics in genetics and each question consisted of four possible choices, followed by the requirement for students to justify the chosen answers.

Semi-structured interview-The pre-post genetic questionnaires were followed by prepost semi-structured interview respectively which consisted of guidelines that covered the same 5 main subtopics in genetics and same guidelines were used in both the interviews to gain more information regarding the students' conceptions and validate the students' responses in the questionnaires.

Reflective journal- was used to record detailed descriptions of the observations made in all the 5 cycles by the researcher and also the observation by a critical friend proved to be very useful for events or actions or something that may not be measurable by the other tools like teacher's behavior or body language or style of facilitation while carrying out the PBL activity and these reflections helped the teacher to improve further. 
Video recordings which served as back up data also helped to reflect when the critical friend was unavailable.

Student's learning tasks- It was used to observe the students' progression throughout the cycle through homework, worksheets, group discussions, presentation charts, reading and research evidences, notes etc.

\section{Data Collection}

The teaching intervention was conducted in 15 teaching periods of 50 minutes each. Pre-genetic test was administered to check students' prior knowledge and understanding of the basic but important concepts that are related to genetics. The post-genetic test with a similar pattern were given at the end of the genetics unit. The responses of the students' answers in both tests were coded and tabulated to count the frequency of the 5 codes (table 1) that were used to judge the students' conceptions, misconceptions or lack of conceptions in the subject matter and these tabulations were used to assess improvements in understanding of the advanced concepts being taught or misconceptions clarified.

Following the assessment of the pre-genetic tests, pre-semi-structured interview was conducted where three students, one from each category of performer (high, medium and low) in the pre-genetic test were selected and interviewed face-to-face for more information as regards to their understanding on the five units under genetics in general at the beginning of the study. At the end of the five units, a similar post -genetic test was administered and the same three students were interviewed again. Participants were audio-taped to subsequently produce verbatim transcriptions of the interviews which were coded and analyzed under the same 5 categories of codes as in table 1 . The purpose of the tests and the interviews were to determine how much of genetic understanding specific of the five subtopics each of the students had at the beginning of the units when they had little or no understanding with more misconceptions or ability to function in a blended PBL and scientific argumentation type class as compared to the end of the units after learning with PBL.

A reflective journal was used by the researcher to record detailed descriptions of the observations made in all the 5 cycles and also the observations by a critical friend who had teaching experience of almost 30 years as a biology teacher. These details were included by date, time and topic throughout the cycle at the end of the day. The focus of the observation was to see how well the researcher blended the two approaches to elicit students' preconceptions, solve common misconceptions, plan activities accordingly to ensure students are learning independently and actively.

Students' learning tasks included preparation of the observation forms that were completed at the end of every cycle, assessment of their homework, presentation charts, group work, follow up activity such as writing and learning the biological terms. The researcher gave worksheets and activity sheets etc. to the students as student tasks, to observe the teaching and learning progression. 


\section{Data Analysis}

Student responses on both the genetic tests and semi-structured interviews were transcribed, coded and analyzed through content analysis which involved reading and judgement. For the analysis process, students' answers to the questions were categorized under five codes (table 1, graph 1). Their answers were corrected and recorded against each question if the students answered correctly. First students' responses under each item were grouped together so that it was easy for the reader to read thoroughly and find clue from each answer about which concepts in genetics were known already, which were unknown and of course the misconceptions. For CU, both the answers given by a student for that particular question should be correct. For PU, the first answer should be right and the second answer should be partially correct. For PU and MC, the first answer should be correct followed by partially correct answer with a misconception in the second answer. For MC, the first answer could be right or wrong followed by a misconception. The last code NO, either both the answers were wrong or students did not write anything. The frequency of the codes was counted, tabulated and converted into percentages for each five sub-topics in genetics. They were drawn into bar graph and the comparison of the pre and post genetic tests tabulated in a summarized form (Norton, 2018).

After grouping the students' answers, the researcher then read the answers thoroughly and used the misconceptions that were identified in the students' feedback to plan the PBL lesson activities accordingly. After categorizing, the data were read and reviewed again to determine any emerging patterns. The utilization of the different data collection methods, i.e. the questionnaires, interviews, observations, reflective journals and student tasks preparation ensured the credibility of the research by implementing method triangulation which made it possible to extract results. The data had also been subjected to peer debriefing, in which research data, the final report, and general methodology had been examined cooperatively by a science educator. Verbatim transcriptions of both preand post-semi-structured interviews formed the database for the analysis. They were coded using the same five codes as in table 1 and tabulated into categories to make a comparative study of their understanding of genetics concepts after the intervention. Towards the end of the post-genetic tests and post semi-structured interviews, only three significant codes i.e. CU, M, NO was analyzed for the result and discussion as they were enough to answer the research question.

The success criteria for the action was to recognize the misconceptions students had and to plan the lesson to clarify those misconceptions by applying a blend of two teaching approaches and how the lesson and the implementation of the approaches was simplified as the lesson proceeded with the next cycle by observing the teaching and learning progression. The method triangulations especially the comments from the critical friend assisted the researcher to maintain the strengths and work to solve the weaknesses in the next cycle. 


\section{FINDINGS}

\section{Teaching Progression in 5 Action Research Cycles}

The comments of the five units below describe the transition of teacher-centred teaching into student-centred teaching with problems being reflected upon and solved in the next cycle and also the transition of students as self-directed independent active learners from passive learners.

\section{Cycle I (inheritance)}

The researcher faced many issues in classroom management while the students seemed distracted because of the implementation of a new strategy. Although the instructions were provided beforehand, students kept asking questions and the researcher had to explain and guide at every step. The researcher had to take the lead role every time and an observer identified that the students were just directed towards the next step. The researcher observed that students were shy, lacked confidence and were reluctant about sharing their opinion in class. They read from their notes during presentations and there was little effort in designing and preparing well while the confident students usually volunteered to present. Scientific argumentation was scarce in this cycle possibly due to students and teachers preferring the traditional teaching. Students also had difficulty with the biological terms. The class was lively even if it was in the afternoon but overall, the implementation of the two approaches was found difficult in cycle I.

\section{Cycle II (variation)}

The researcher improved the lesson plan based on the problems identified in cycle I and gradually introduced PBL with scientific argumentation strategy step by step. Students were provided with printed worksheets with rubrics so that they were directed well for the activity and asked to practice pronouncing biological terms and take notes. The researcher encouraged teamwork and encouraged distracted students to participate more. Students were randomly selected to present in class ensuring that all students were prepared for the presentation and assessed during presentation and scientific argumentation with attention to understanding of biological terms. The researcher took part in the discussion to keep the students focused, which was appreciated by the critical friend. Usage of the Internet saved time with the assistance from the researcher in finding information on authentic websites. Students were found to be actively engaged in the activity but they found the steps of the interventions complicated and still needed to work on their biological terms. They were still shy and some were distracted during the group work. The critical friend pointed out that assessing the presentation made by a random student for their group was not fair, although it kept the students focused and engaged in class.

\section{Cycle III (genetic engineering)}

The lesson plan in cycle III was improved based on the reflections of cycle II. The researcher had to read and find articles on genetically modified organisms (GMO) to fulfil the objective of the lesson. The blending of the two approaches into six simplified 
steps was welcomed by the students at this stage and they were excited about the lesson and explored for information beyond the lesson's mandate but it led to more time being spent on looking for solutions, evidence and justifications. The researcher was pleased to observe that the students were efficient with their smartphones and usage of the Internet. With the students now comfortable with the procedure, they could now focus on the concepts and search the internet for evidence and justifications for their solutions.

Other members of the groups were allowed to join in the discussion after the presentation and it was observed that it fostered collaboration and harmony making the classes interesting and manageable. Presenting as a group boosted their confidence. The researcher observed that students still struggled with the terminologies.

\section{Cycle IV (cloning)}

The lesson plan in cycle IV improved based upon the reflections of cycle III. The six simplified steps of the intervention and the writing the meaning of the biological terms listed in the activity sheet made the lesson easy for the teacher to conduct and students found the simplified step very easy to follow. Students need not write the group discussion worksheet twice for part 1 and 2 separately but together and made changes in their hypotheses. All the solutions of the six groups were discussed in the end after their presentations and opened the floor for argumentation. The students chose the best solution that they considered to be applicable in the future. While the researcher had to give clear instructions at this point, the students nonetheless carried the activity forward independently in the $1^{\text {st }}$ period of the cycle. In the $2^{\text {nd }}$ period, students got together, discussed their solutions in small groups and chose one best solution for presentation collaboratively. In the $3^{\text {rd }}$ period of the cycle, students' names were called upon to present. The facilitator discussed proposed solutions with the whole group to choose the best solution. The researcher observed that the students argued scientifically, did not read their notes and were no longer shy. The researcher's role was to trigger the argument by asking questions in order to keep the discussion flowing in the right direction. The researcher continued to monitor each group and helped them stay on track by asking relevant questions or finding a valid source or link or provide reading materials and other resources. Students were observed to follow the step of PBL with scientific argumentation independently without much help from the teacher. The role of the teacher at this point was to ensure the students are carrying out their activity well and looking for correct information, facilitating the group activity and encouraging students to think by asking thought provoking questions. Students required more practice.

\section{Cycle V (evolution)}

The lesson on evolution in cycle $\mathrm{V}$ was improved by the reflections of cycle IV. This time the improvised or simplified PBL, together with the scientific argumentation, was observed to be easy for the students to comprehend and the students knew exactly what to do. At this stage, students and teacher were comfortable with the role reversal. The researcher's role became less directed as the students carried out the activity more independently. The students' confidence level had also improved during argumentation sessions as compared to the initial stages. The researcher observed that students learned 
much more deeply with less stress and the teacher also felt less stressful as most of the misconceptions were clarified during their discussion following the scientific argumentation. Time management depended on the difficulty of the unit taught.

\section{Students' Progression in Genetic Concepts}

The result of the analysis of the pre and post-genetic tests, supported by the analysis of the interviews, was that the intervention helped to understand the basic concepts of genetics and clarified most of the misconceptions. The summary of the results is illustrated in Table 1 and graph 1.

Table 1

The result of the analysis of the pre and post-genetic tests

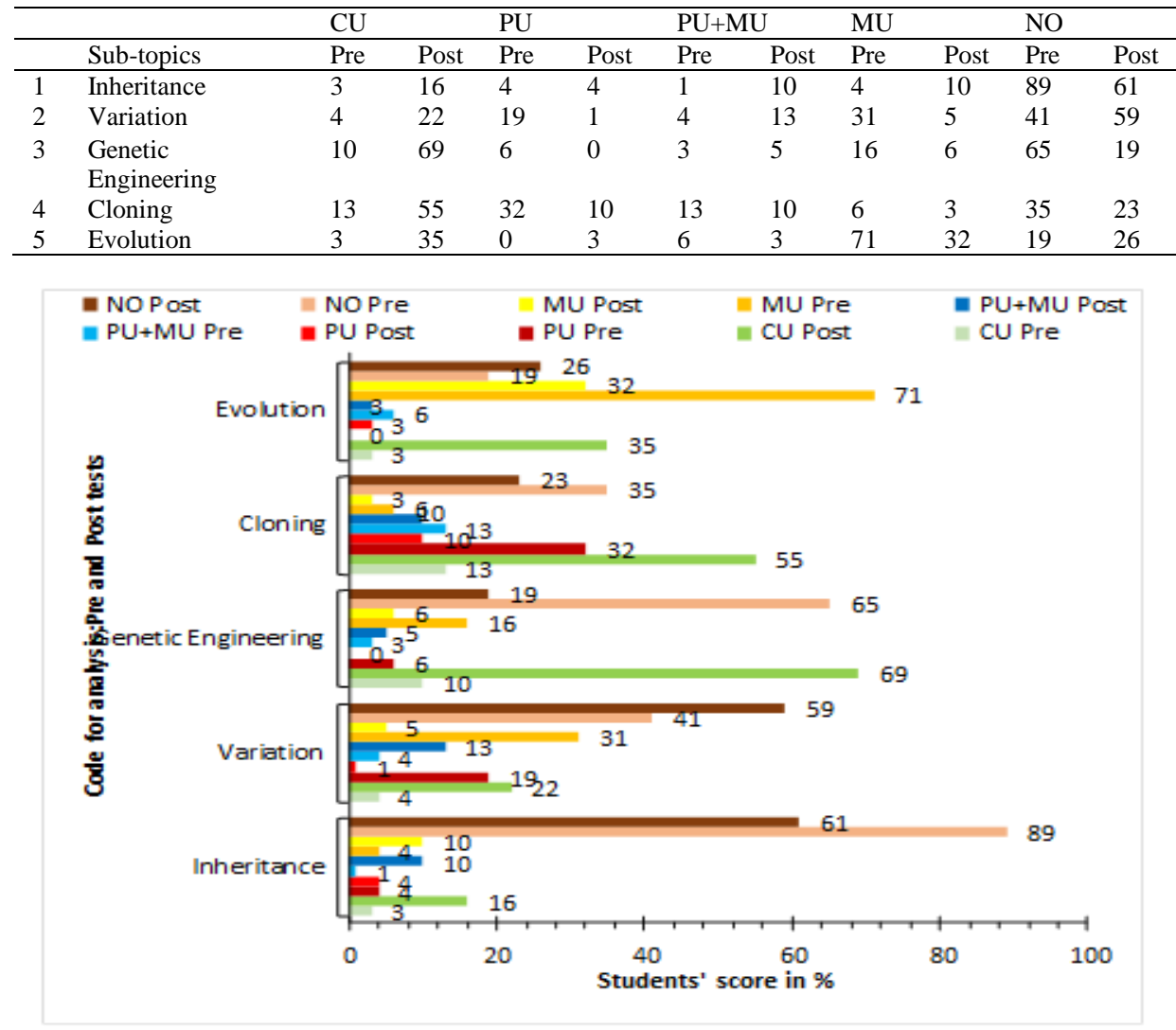

Figure 1

Codes for analysis

Note: CU (Complete understanding): The student has a level of understanding similar to a scientist. PU (Partial understanding): The student has some ideas similar to a scientist. PU+MU (Partial understanding with misconception): The student has some ideas similar 
to a scientist but they also have misconceptions. MU (Misunderstanding): The student does not have ideas similar to scientists and has misunderstandings. NO (Don't understand): The student has no ideas about the concept or did not write anything.

The overall result highlights the three main categories for the discussion and that there is complete understanding, misunderstanding and no understanding, as shown in table 1(bar graph). The order of topics, students' had complete understanding in the postgenetic test are in genetic engineering, cloning, evolution, variation and lastly inheritance respectively. Positive result across all topics indicated remarkable improvement in the post-genetic test when compared to the pre-genetic test in the complete understanding category. The order of topics students had the most misunderstandings are evolution, variation, genetic engineering, cloning and inheritance respectively in the pre- genetic test. There were positive results on all the topics when pre and post-genetics test scores were compared after the intervention. It was observed that students initially did not have much idea on genetics before the intervention but the results of the post-genetic test revealed that they understood most concepts and most misconceptions clarified.

A few examples of their conceptions and misconceptions of some concepts are compiled and compared as follows from the pre and post-genetic tests and also from the pre and post interview as follows.

Student's preconception of the role of DNA was limited to parental identification, which made the researcher perceive that the students did know something about the role of DNA but at the same time, DNA and genes were used by most student interchangeably. Most did not answer item number 8 that questions the relationship between the gene, DNA and chromosomes and this was the emerging problem that required attention. In the post-genetic test result, it was revealed that students understood the difference between genes, DNA and chromosomes (Dorji et al., 2017).

Another misconception, students had in genetic engineering was that most students said that strawberries with different colors were due to people injecting colors into them. The extract from the post interview revealed that the misconception was clarified after the intervention when the same question was asked. Most of students' responded saying, "They take out the blue genes from blue berry and planted in the DNA of a red strawberry or apple and the blue color became dominant".

So, the positive result indicates that this intervention proved to be successful in clarifying most of the misunderstandings pertaining to the 5 units in genetics.

\section{DISCUSSION}

Inheritance was the most difficult unit for students to understand followed by evolution, variation, genetic engineering and cloning (see Table 1 and Graph 1). The teaching difficulty with inheritance may well be due to the fact that the subject of inheritance is generally considered very challenging to teach (Ibourk et al., 2018).Other factors considered are teaching approaches and teacher time being used on new methods rather than on the concepts during the first unit of study (Haambokoma, 2007; Mustami, 2016). 
The problem of lack of a working biological vocabulary (mutation, genotype, phenotype, homologous, alleles etc.) was prevalent in all units. To address this, the researcher asked students to study the definitions of particular biological terms based on action research assessment as a home task and this was observed to have a positive impact on their confidence and use of the biological terminologies during scientific argumentation. This observation was similar to that of Tibell \& Harms (2017) who also mentioned in their study that the students' confidence in presentation and scientific argumentations heavily depended on the use of biological terms.

The PBL activities related to genetics encouraged the students to be active and engaged even in the afternoon classes also observed by Jimenez-Aleixandre et al (2010). At the beginning of the study this independence was slower because much time was spent introducing and learning the blended approach but the issue with time management improved with practice and the students were comfortable with the PBL steps and could concentrate on the lesson. The blended approach was more of an influence from cycle II onwards having adjusted to a non-traditional approach which was then made simpler according to the students' context or understanding around cycle III which was practiced again in cycle IV.

The researcher as a facilitator and participant helped students to solve problems in genetics and work collaboratively, overcome their shyness and boost their confidence but it was observed that students struggled to find evidence to support their solution and the teacher had to intervene frequently and help them find the correct information. The process of blending PBL with scientific argumentation also encouraged deeper learning. These similar positive outcomes of the results using these two approaches together were also supported by Belland et al (2011).

The researcher observed that classroom action research was not only reflective of the teacher's own teaching strengths and weakness but provided time for individual and small group guidance because the teacher was freed from lecturing. The researcher's role in classroom teaching was reduced gradually when compared to the initial cycles and also students were observed to be more independent and active learners by cycle $\mathrm{V}$. Students were observed to be more confident in their presentation and argumentation and worked collaboratively in groups. The lack of high-speed internet in the computer room and reference books in the library made the researcher explore the use of mobile technology and it was found to be the fastest means to acquire information or knowledge as students were already acquainted with the use of smartphones. Most of these outcomes are supported by similar results found in studies done by Cavagnetto (2010); Chung et al (2016); Wirkala \& Kuhn (2011).

\section{CONCLUSION AND RECOMMENDATIONS}

Based on the results of the content analysis and method triangulation student understanding of basic genetics improved in all five subtopics by blending problembased learning with scientific argumentation. The method proved to be an effective active teaching and learning approach for teaching basic genetics as it was observed to clarify most student misconceptions in genetics. The students were observed to enjoy the 
lessons and explored topics much deeper beyond what was prescribed by the syllabus as self-directed, independent learners. The improvement of the lessons with the implementation of the blend of two approaches was assessed regularly by classroom action research. This model enabled the researcher to reflect on her teaching style and find practical solutions to overcome the misconceptions or problems students had in genetics in the classroom through the spiral of plan, act, observe and reflect. This helped the researcher to realize the effectiveness of the new active teaching and learning approaches to be beneficial for teaching and understanding a difficult concept such as genetics. It also helped to reflect the important role of a teacher as a facilitator to encourage and implement the student-centred active learning strategy that showed positive results.

However, it should be noted that the current study was limited to the implementation of the intervention in a science unit on Genetics and to grade 9 students from one school for six weeks only and the teacher of the study was not an expert in genetics or the approaches so if an expert taught these units, then perhaps the result would have been even more significant. Therefore, there is a need for replicating this study especially in science with larger sample and in other high schools in other countries and share the outcome of the study.

Teachers can use the blending of PBL with scientific argumentation as a role reversal teaching strategy to improve teacher's mind-set about traditional teaching style and to make our students into active, independent, and confident learners. The study encourages the integration of mobile technology as it was observed to support the intervention positively. It is also recommended for researchers to study the impact of this approach on the students and teachers or perhaps study of change of attitude of students and teachers before and after the intervention towards genetics. Study of the importance of knowing the biological terms or scientific words for better scientific argumentation could be another study recommended for future researchers.

\section{Conflict of interest}

There is no conflict of interest.

\section{REFERENCES}

Altunoğlu, B. D., \& Şeker, M. (2015). The understandings of genetics concepts and learning approach of pre-service science teachers. Journal of Educational and Social Research, 5(1 S1), 61-66. doi: 10.5901/jesr.2015.v5n1s1p61.

Araz, G., \& Sungur, S. (2007). Effectiveness of problem-based learning on academic performance in genetics. Biochemistry and Molecular Biology Edu., 35(6), 448-451.

Baele, L. C. (2017). Middle school engineering problem solving using traditional vs. $e$ PBL module instruction (Unpublished doctoral dissertation). Aurora University, Illinois. 
Belland, B. R., Glazewski, K. D., \& Richardson, J. C. (2011). Problem-based learning and argumentation: testing a scaffolding framework to support middle school students' creation of evidence-based arguments. Instructional Science, 39(5), 667-694. doi:10.1007/s11251-010-9148-z.

Barrett, T., \& Moore, S. (2010). New approaches to problem-based learning: Revitalising your practice in higher education. New York: Routledge.

Cavagnetto, A. R. (2010). Argument to foster scientific literacy: A review of argument interventions in K-12 science contexts. Review of Educational Res., 80(3), 336-371.

Chung, P., Yeh, R. C., \& Chen, Y.C. (2016). Influence of problem-based learning strategy on enhancing student's industrial oriented competences learned: an action research on learning weblog analysis. Int. J. of Tech. and Desi. Edu., 26(2), 285-307.

Costello, P. J. M. (2011). Effective action research : developing reflective thinking and practice. London: Continuum International Publishing.

DCRD. (2011). Ministry of Education, RGOB. Science curriculum framework PP-XII Retrieved from http://www.ibe.unesco.org/curricula/bhutan/bt_al_sc_2011_eng.pdf.

Dolma, P., Nutchey, D., Watters, J. J., \& Chandra, V. (2018). Investigating the alignment of Bhutanese mathematics teachers' planned approaches within the context of a reformed curriculum. Int. J. of Science and Mathematics Education, 16(3), 581-602.

Donnelly, R. (2006). Blended problem-based learning for teacher education: lessons learnt. Learning, Media and Technology, 31(2), 93-116.

Dorji, K., Tshering, P., \& Dorji, U. (2017). Understanding of genetic entities: Exploration of Bhutanese students' conceptual status. Rabsel - the CERD Educational Journal, 18(2), 11-25.

Dorji, K. \& Sriwattanarothai, N. (2015). Hands on activities to link gene mutations with three-dimensional protein structures for high school students. Paper presented at the INTED2015 Conference, Madrid, Spain.

Fernandez, F. B. (2017). Action research in the physics classroom: the impact of authentic, inquiry based learning or instruction on the learning of thermal physics. AsiaPacific Science Education, 3: 3. doi: 10.1186/s41029-017-0014-z.

Fielding-Wells, J. (2015). Identifying core elements of argument-based inquiry in primary mathematics learning. In M. Marshman, V. Geiger, \& A. Bennison (Eds.), Mathematics education in the margins (Proceedings of the 38th Annual Conference of the Mathematics Education Research Group of Australasia) (pp.229-236). Sunshine Coast: MERGA.

Hien, T. T. T. (2016). Why is action research suitable for education? VNU Journal of Science, Foreign Studies, 25(2), 97-106. 
Hine, G. S. C. (2013). The importance of action research in teacher education programs. Western Australia's TL Forum. Issues in Educational Research, 23(2), 151-163.

Jimenez-Aleixandre, M. P., Mauriz, B. P., Gallástegui Otero, J. R., \& Blake, A. (2010). Report on argumentation and teacher education in Europe. Retrieved from https://strathprints.strah.ac.uk/id/eprint/31905.

Ju, H., \& Choi, I. (2018). The role of argumentation in hypothetico-deductive reasoning during problem-based learning in medical education: A conceptual framework. Interdisciplinary J. of Problem-based Learning, 12(1): 4. doi: 10.7771/15415015.1638 .

Kemmis, S., \& McTaggart, R. (2005). Participatory action research: Communicative action and the public sphere. In N. K. Denzin, \& Y. S. Lincoln (Eds.), The sage handbook of qualitative research (pp.559-603). Thousand Oaks, CA: Sage.

Kılıç, D., \& Sağlam, N. (2014). Students' understanding of genetics concepts: the effect of reasoning ability and learning approaches. J. of Biological Education, 48(2), 63-70.

Marra, R. M., Jonassen, D. H., Palmer, B., \& Luft, S. (2014). Why problem-based learning works: Theoretical foundations. J. on Excel. in Col. Teach., 25(3/4), 221-238.

Maxwell, T. (2003). Action research for Bhutan? Rabsel, III, 1-20. Retrieved from https://www.pce.edu.bt/cerd-publications-2/.

McConnell, T., Parker, J., \& Eberhardt, J. (2016). Problem-based learning in the life science classroom, $K-12$. Arlington, VA: NSTA Press.

Mustami, M. K. (2016). Identifying the misconceptions in students' biology department on genetics concept with CRI Method. The Social Sciences, 11(13), 3348-3351

Namgyel, S. (2005). What are the students' preferred teaching-learning methods and strategies in the Bhutanese education system module? An inward journey to improve delivery: An action research report. RABSEL 7. Paro, Bhutan: CERD.

NIH. (2010). The new genetics. U.S.A: Office of Communications and Public Liaison. National Institute of General Medical Sciences.National Institutes of Health.U.S. Department of Health and Human Services.

Norton, L. (2018). Action research in teaching and learning: A practical guide to conducting pedagogical research in universities. Routledge.

Osman, E., BouJaoude, S., \& Hamdan, H. (2017). An investigation of Lebanese G7-12 students' misconceptions and difficulties in genetics and their genetics literacy. International Journal of Science and Mathematics Education, 15(7), 1257-1280. 
Pei, B., Xing, W., \& Lee, H. S. (2019). Using automatic image processing to analyze visual artifacts created by students in scientific argumentation. British Journal of Educational Technology, online first. doi: 10.1111/bjet.12741.

Putri, L., Rahman, T., \& Priyandoko, D. (2017). Analyzing concepts mastery and misconceptions about evolution of biology major students. Journal of Physics Conference Series, 812(1), 012083. doi: 10.1088/1742-6596/812/1/012083.

Queloz, A. C., Klymkowsky, M. W., Stern, E., Hafen, E., \& Köhler, K. (2017). Diagnostic of students' misconceptions using the biological concepts instrument (BCI): A method for conducting an educational needs assessment. PloS one, 12(5), e0176906. doi: 10.1371/journal.pone.0176906. eCollection 2017.

Rodríguez, M., Díaz, I., Gonzalez, E. J., \& González-Miquel, M. (2018). Motivational active learning: An integrated approach to teaching and learning process control. Education for Chemical Engineers, 24, 7-12.

Royal Education Council. (2016). curriculum, syllabus. Retrieved from http://rec.gov.bt/.

Sage, S., \& Torp, L. (2002). Problem as possibilities: Problem-based learning for K-16 education. Alexandria, VA: Association for Supervision and Curriculum Development.

Sampson, V., Grooms, J., \& Walker, J. P. (2011). Argument-driven Inquiry as a way to help students learn how to participate in scientific argumentation and craft written arguments: An exploratory study. Science Education, 95(2), 217-257.

Sanders, M., \& Makotsa, D. (2016). The possible influence of curriculum statements and textbooks on misconceptions: The case of evolution. Edu. as Change, 20(1), 1-23.

Shaw, K. M., Van Horne, K., Zhang, H., \& Boughman, J. (2008). Essay contest reveals misconceptions of high school students in genetics content. Genetics, 178(3), 11571168. doi: 10.1534/genetics.107.084194.

Suarez, S. M. (2017). Effectiveness of problem-based learning in academic performance of course "Physics I". Paper presented at the IEEE Frontiers in Education Conference, Indianapolis, Indiana.

Tibell, L. A., \& Harms, U. (2017). Biological principles and threshold concepts for understanding natural selection. Science \& Education, 26(7/9), 953-973.

Toulmin, S. E. (2003). The uses of argument. Cambridge University.

Wirkala, C., \& Kuhn, D. (2011). Problem-based learning in k-12 education: Is it effective and how does it achieve its effects? American Educational Research Journal, 48(5), 1157-1186. doi: 10.3102/0002831211419491. 
Zahrok, H., Supeno, \& Lesmono, A. D. (2017). Students' argumentation skills through PMA learning in vocational school. The International Journal of Social Sciences and Humanities Invention 4(7), 3619-3624. doi: 10.18535/ijsshi/v4i7.08. 